\title{
Study of Orientation and News Coverage about Daesh Crisis in Websites of IRNA, BBC and Voice of America
}

\author{
Hamidreza Yarmohammadi ${ }^{1} \&$ Hajimohammad Ahmadi ${ }^{2}$ \\ ${ }^{1}$ Tabriz Branch, Islamic Azad University, Tabriz, Iran \\ ${ }^{2}$ Faculty of Social Communication Sciences, Central Tehran Branch, Islamic Azad University, Tehran, Iran \\ Correspondence: Hamidreza Yarmohammadi, Tabriz Branch, Islamic Azad University, Tabriz, Iran. E-mail: \\ hamidrezayarmohammadi94@gmail.com
}

\author{
Received: May 15, 2016 Accepted: June 24, 2016 Online Published: July 21, 2016 \\ doi:10.5539/jpl.v9n7p15 URL: http://dx.doi.org/10.5539/jpl.v9n7p15
}

\begin{abstract}
This paper, entitled "Study of orientation and news coverage about Daesh crisis by websites of IRNA, BBC Persian and Voice of America", comparatively explores structure and how to cover news in websites of IRNA, $\mathrm{BBC}$ Persian and the voice of America. The paper is conducted in descriptive-analytical method and by the way of content analysis. Data has been studied in library method. Survey and examination of existing documents as well as analysis of the content of news websites are presented in descriptive tables. The type of organization and how to cover news differ in three websites of BBC and IRNA, Voice of America. Every three websites have specifically emphasized on the element "who", "news value" and "fame", indicating their person-oriented and talk orientation. Finally, it was concluded that most published news are "non-productive" in three websites, however IRNA's portion is more than others. Conceptually, the issue of Daesh group resistance, the employment of Jihadi groups, the effort to manifest Daesh an Islamic group, introducing Daesh governmental philosophy as an Islamic government and not mentionning to its terrorist nature has been under survey and attention of these three websites. The focus of IRNA and Voice of America is mostly on "hard news" but BBC concentrates on "soft news" or reflection of events along with complementary information. Publication of "photo" has been used as interactive and multi-media facilities by news websites. Unlike IRNA, websites of BBC and Voice of America have highly made use of Email and links to topics and relevant websites.
\end{abstract}

Keywords: news, Iran, news websites, IRNA, BBC, the voice of America, content analysis

\section{Introduction}

History of media goes back to entire human life, and it has been always used as a tool to attain human's objectives in various aspects. As human society develops, media has turned into an instrument to defend foreign policies as well as to value and convey message. It also plays a justifying role of public perspectives in the area of foreign policy by legitimating state policies and conveying messages to those involved in diplomacy. In this concept, media acts as disseminator of culture, beliefs, informer of ideology and ideas of country's foreign policy. Meanwhile, as representative of civil society institutions, non-governmental organization, multi-nation companies and public thought, media plays a major role in clarifying issues on foreign policy. Contrary to traditional media, modern media use technology for their development. Humankind has always applied media to convey meaning and concept to others. In this regard, language is also regarded as a media; as it is a tool to convey meaning to others. Speech and lecture are also other forms of traditional media where technology does not interfere in their formation. Nowadays, world events have formed part of everyday life and what take place throughout the world is locally seen as an aspect of world condition. At such integrated world, it is reasonable to assume that as a particular event has happened in one place it may directly or indirectly influence B, C and D place or even the whole world. This is the case about world health and warnings that are issued on the incidence of an epidemic such as Ebola virus in western Africa or warning about international terrorism. So some networks, like BBC, succeed to cover and organize their news through their instrument and equipment. (BBC News, 2014).

Media diplomacy is a concept that is considered a paradigm according to the perspective of some media thinkers, so paradigm shifts in communication and diplomacy has produced a new paradigm of policy world that is called "Telediplomacy" (Ammon, 2001: 30). Moreover, some theorists has defined media diplomacy as " the use of mass media to communicate governmental and non-governmental players towards building confidence, talk 
progress and public support mobilization of agreement (Gilboa, 2009: 53). Therefore, it seems that two approaches have always been dominated in media diplomatic occasions, approach in which media is regarded as tool to influence public and the other one is that media is considered as concept of media diplomacy irrespective of public diplomacy concept.

As alternative information producer for mainstream media that mainly looks for challenging existing powers, whether commercial function or political support function, and nation's possession, media like internet acts to promote communication among included societies represented by marginalized groups (Joyce, 2012: 21). Furthermore, internet world network and transnational group media, like digital and satellite television, play a critical role to create a connection between local and national territories, exchange information, enhance interaction between different players and to develop informed citizen.

Regarding research related to current study, it is possible to explain Claude research entitled media, symbolic power and Bourdieu theory limitations which address social theory (even if they are most interrelated with media, ideological analysis, post-modern theory and system theory) and how media affect its key concepts. In his research, he knows reformed-version Bourdieu theory as the best starting point. He further continue by the mention that even though media production analysis is not a new and special string, string theory is not compatible with the idea that media representation affect all social space at the same time. The solution is that we less relies on Bourdieu recognized effect on symbolic power and prescriptive power which is analogy between media social center and Bourdieu report of Tran capital between all strings. Empirical research instruction has been mentioned and (in conclusion) a theoretical issue has been predicted (How media affects Bourdieu idea on person?) and author tend to address it in a separated article (Couldry, 2003: 1).

In 2012 and in a research titled terrorism and mass media, Persin examines a new pattern of terrorism that is partially the outcome of sudden development of information technology and terrorist organizations were informed of the importance that mass media has to attaint their objectives, because media industry models moves towards sense inspiring potential to produce media content, while terrorist organization can have the highest attendance in media due to their measures. Terrorist organizations constantly try to employ open media to harness their goals. It is stated that mass media provide overall access to terrorism, affect public awareness of terrorism and its risk, political decision made in response to terrorist and relations formed through national and international policy. However, media has not to turn into a terrorist tool. Media can be turned into a weapon in thoughtful way by western countries and it is used as key means to defeat terrorist. Therefore, its benefits are surely more than its undesirable consequences caused by irresponsible measures of journalists or Media Company.

As measures of Daesh terrorist group is very dangerous and they take life of many innocent people and attack cities and lands, in this regard, it is highly significant to raise public awareness on this hazardous crisis and to address its consequences. Thus, News websites can play a very crucial role. It should be stated that as measure conducted by this terrorist group threaten more and more people, the research's importance is revealed more than before, as a result survey of orientation an how to cover news on Daesh crisis through websites of IRNA, BBC Persian and Voice of America is highly significant, actually it is essential to study News sites to find the cause of conflict and also to uproot the crisis in the region. State policy makers and programmers can benefit this type of research.

\section{Subject Headings}

Daesh crisis

New definition of terrorism is a tricky or preprogrammed reaction that is performed by the pressure of organized groups. Their purpose is to achieve financial, religious, political properties for any ideological motive which is supported by systematically implementing violence, threat or violent actions. Their violent actions openly target people, social groups, decision maker's mechanism or their properties. However, the objective is to attain financial, ideological and political benefits of government or political system. Throughout the history, terrorist was not able to overthrow eastern regimes and it has actually became a threat for order and stabilized power, it should be also mentioned that the most remarkable aspect of terrorist is its psychological impact that is organized by mass media and it eventually leads to subsequent trick and chaos. In this context, taking any measures against terrorist is acceptable. In general terms, terrorism scenario causes social injustice, disagreement and conflicts between disadvantaged and poor east world and wealthy west (Eid \& Cheong, 2014).

Finally we should be mentioned that Daesh actions in a region are very perilous. This group advocates some strict regulations that violate Islamic law. Ridiculous orders are issued by this group including sexual Jihad, self-sexual jihad, and anal Jihad that are well performed in Syria. They take piety position and starts killing 
innocent people in Iraq and Syria, while they don't worry Sunni minority at all but their main concern is to achieve and attain rich resources of every city and region. To draw people attention, they promise to provide water, cheap electricity and more security for occupied cities, while they plunder citizen's property by taking high tolls. In fact it has to be stated that Daesh group calls for establishing Sunni Islamic government in Iraq and Syria border where Kurdistan and land of Shia are located, and this goal has to be fulfilled at any way possible (Silver, 2013: 23).

United States also shows his ill will against Iraq events by taking current employment and they professed to their close relationship with Daesh. Erdogan's government beside other countries like Saudi Arabia, Qatar, Jordan, and Israel did their utmost efforts to accompany this terrorist group (From sending weapon to treat Daesh's wounded forces). As many analyzers have anticipated, we should witness that division and sedition may fall them into the conflict too and it becomes a torment. Removing this malignant node from Middle East region is the most necessary goal for international society. Soon or late we should wait to see the sovereignty of Abu Bakr al-Baghdadi in various parts of the world (Ibid, 25).

\section{Websites representing the media discourse conflicts scene in different countries}

Higher capacity of serially data exchange has made numbered data to be stored and displayed in a feasible way for user's application. Therefore, some theorists like Jim Carrey believes that web is a world media with the ability to collect and disseminate international news so that it has significantly diminished high difference between News world and real world (Wu, 2007: 37).

Study of this trend demonstrates that internet penetration factor has averagely doubled every three years over the last decade in Iran. In the meantime, based on the last data, nearly a total of $54 \%$ internet users in the Middle East reside in Iran. For international Persian language media we should say that presenting show in foreign language (like Persian) at international news network, such as Voice of America and BBC counts not only a cultural penetration but also honor factor. So that some researchers believes that high reliance of News organization like radio and TV gives a semi-official feature to information and news (Niels, 2012: 17).

\section{News stream at international system}

Johan Galtung raised four models for studying international News process in 1970s that include: the first model, focus theory that has developed in Imperialism structural theory. In this theory, the world is divided into two parts: center or dominant society that is referred to dependent area. The hypothesis can be summarized into four parts that determine status of international News: News events "center" that are reported in world press system are highly authentic. News exchange level with other nations "center" and "around" and exchange level inside nations "center" differs very high. Nation center News covers more foreign events for nation center media. "News stream" is roughly insignificant among "around" nations, this is especially true for boundaries existed by more colonialism. The second model is based on the assumption that News stream is a vertical stream. It theorizes that News stream moves from developed countries (North) to developing countries (South) as well as horizontal streams inside north and south where the second volume is less than first. Is completes it (Melnick, 2010: 17).

While News stream desirably generates from south to the north, but it significantly contains less volume as compared to News stream volume from north to the south. Moreover, in North model- there is directional south which is called orbital stream. In this stream those News gathered by north reporters in the south are sent to the north for processing and edition before returning to south media. There are immense studies that have addressed south and north assumption. Riz Mata who studied American Latin newspapers in 1975 is among aforesaid researchers. His research showed that foreign News in Latin America is dominated by north News stream. Conducted studies in the late 1977 on News stream in 9 Arabian countries also represent dominant presence of south stream in the region (Nellis, 2012: 19).

Kapalan's research on American media, particularly in covering developing world events, has shown a public deficiency in volume, field and type of published News. Major News agency of developed countries such as Associated Press, United Press International, Agence France-Presse, Reuters and dice cover news for local recipients. For American newspapers, it is formed in association with wealth, elitism and potential political power of readers. The third model is a triangle model that divides north to west and east and then connects each of them to the south.

In one of the most comprehensive research based on News geography, George Graebner and William Marwan concluded that west and east have prioritized strategic regions and their relations in foreign News; while the third world media generally dedicates major part of foreign News to the north, i.e. west and east (Marcu, 2014: 23). 
They also found that Western Europe is the most fixed area around which reports are produced from every corner of the world. Conducted research indicates that facility inequality, shortage of expert and skillful forces are the main cause of informational dependence of the third world countries. Lack of a political, economic and social guideline among countries has also led to conflict and dissemination and consequently overall communication weakness of the third world. Among other reasons for communication weakness, we can refer to illiteracy, economic lag as well as management weakness in planning, coordination and performance. Unfortunately, although every efforts are made by the third News Agency to free Media Imperialism dominance in recent decades, more than three quarters of the third world indigenous News come from world famous News Agency. Anyway, owing to the existence of different political structures, geographical distribution, difference in ideology, economic discrepancy in terms of structure and productive system, lack of an international common language the third mass media and communication gain no support and it is impossible to include them in a united and comprehensive framework. This is a reality that media imperialism manifests black as white and vice versa by using various techniques. In the other hand, western News Agency often prevents his international audience minds of dealing with catastrophe truth of Dominated communities by presenting insignificant and dramatic issue. In addition, giving unilateral value to industrial world news, minimization, deletion, distortion of the third world news, news highlighting, status instability in western news agency of developing countries should be questioned. These News Agencies try to depict an incorrect image of them by relying on disasters, crisis, conflicts and painful news of the third world. They behave them ethnically and try to satisfy News Market dominated by West (Nellis, 2012: 25).

\section{Soft power}

Soft power is a new term spread by Joseph Nye, contemporary theorist, and it is frequently applied by communication expert and scientist in recent years. In fact soft power control all humankind facility and capabilities in soft-ware and cyber domain to form other preference.

The introduced capabilities are to influence human performance and thought without bloodshed. So it includes various written and non-written media ranging from audio and video media to dominance on mental war techniques (Nye, 2008: 61).

\section{International media and features of information}

In a general view, it can be stated that significant part of international information stream and news happen in technology and broadcasting methods. In this sense, three research areas have reserved the major position at international communication that include television, international radio broadcasting, technology of international relations and satellite live broadcasting. Online streaming radio consider researchers and experts of mass media devices "radio" as a protagonist mass media and it had a history of nine decades (Archetti, 2012: 16).

Moreover, in general terms, modern media develops in world internet network and that follow special principles that distinguish them from traditional media. "Lee Manoich", researcher of modern communication, writes in his book, media identity is significantly changing at any moment. He mentions "numerical display ability", "single-formation", "organization", "automation", "variability" and "ultra-coding" as fundamental differences between traditional and modern media (Ibid, 19).

Traditional paradigm of communication and its dimensions have wonderfully changed as internet communication develops. Among diverse functions of internet communication, Everett Rogers has referred to three features "interactivity", "non- synchronicity" and "summation". Interactivity is the main characteristic of modern communication systems. Actually, modern media integrates together two collective and face-to-face state. Non- synchronicity means that person has the ability to send or receive his ideal message at desirable time. It allows one to work with a computer network at his own house, so the person is more flexible and changeable in terms of time and place (Tilis, 2013: 16).

Summation is meant that new media interact more or less with collective media. So through this technology, we have to move from a collective communication to a more advanced form of public face-to-face communication and this is why researcher and scientists name internet communication as "inter-personal collective communication device". Dennis Wu \& Araty Bechel, in their research entitled "the use of website, topic and type of news" consider three features for a fascinating internet News users. These two researchers believe that "inconsistency", "thematic or fragmentation" and "predictability" are three features of internet News that would lead to the more reference to website and higher frequency of user's visit to internet media. Inconsistency is defined as immediate, momentary and dissociative features of News. The more dissociation of News, the more rate of success to call's readers attention. Meanwhile, researcher believes if readers informs of an event at a certain time (such as a political celebration or sport competition), they more probably will visit the website to 
know about the time of adventure (Al-Alam News network, 2013).

\section{News arrangement theories}

Highlighting theory:

In many occasions, research history in communication is the same research history in effects. In the first stage, it is thought mass media has impressive influence. The theory was dominated years between World War I and II. Terms like magic bullet and needles describes this stage. The second stage was introduced. Researcher estimates duration of this period from World War II to 1970s. Since then many researchers have advocated the concept of powerful mass media. As stated at introduction and statement of problem, experts have defined TV News arrangement as highlighting on change and effect in reader's behavior and they know highlighting the nearest concept to News arrangement. During highlighting and arrangement, they also declare factors like News goalkeeping, prioritization and balance as three effective factors when facing with News topic selection. McCombs and Shaw first used the term highlighting to describe a phenomenon that had been recognized in the course of election competitions for many years. It is named as a strategic power. Thus, highlighting can be considered one of effective techniques in massage sending process for affecting readers and according to McCoail perspective, 2009, its purpose is:

1) Creating intentional change

2) Creating unintentional change

3) Creating formal change

4) Facilitating change trend

5) Elevating attitudes and beliefs

6) Prohibition of change

Celper believes that mass media does not directly affect reader but it act as a mediator. "mediating role of media can be regarded as the necessity of information and communication activities in current complicated world. Thus having all information available is not possible without media. Mediating role refers to different definition that goes back to types of communication between us and reality of media". Goulding (1981) divides media influence into three categories to distinguish various concepts of news and media impression. He defines unconscious orientation and long term works as "unwanted short term works and orientation" and long term conscious works is defined as ideology (2013, Al-Alam news network).

According to Trnaman's research, there are some reasons that massages come from a reliable and credible source are relatively effective, so massages is issued from favorable source. For content, the influence is accompanied by repetition, stability and lack of alternatives and the probability of influence would increase if it is objective and with no ambiguity. Among theories related to media works, Shomiker and Rogers's perspective is also noteworthy. Their model include four stages: raising awareness, satisfaction, decision making, acceptance or confirmation. In this view, the first stage refers to the media's role as notifying source and other stages relates to personal relationship, organized skill, consultation, and practical experience of acceptance process. Of course, other theories consider a relatively slight role for mass media and know its effectiveness provided that more closeness to society and native culture. Findings of Ternaman and Mc Coail (1961) indicate people think about what is said to them, but they don't think what is told them at every level. Existing evidence announce a kind of accordance between the importance of topic for media, public and News politicians. This is the essence of highlighting theory. Denis Mc Coail emphasizes we require a combination of content analysis in order to describe the connections among highlight's type, not only it shows media's attention to different topics, but also include the attention of readers to media.

\section{Relationship between Media and Terrorism}

The spread of terrorism in the world has been unprecedented in human's history so media progress, easiness of collective and personal interactions contributes to it. Now the question is if terrorism is able to develop without media support or News coverage encourages terrorist actions and its perpetrator, if media play role in disseminating terrorist's culture and if it finally lead to more violence and terrorism level? Hence, anyone who is seeking to perform party, personal, governmental political plan should think of having a media in advance (Architti, 2012: 51).

Undoubtedly, terrorism phenomenon is important for everyone because of its dangerous consequences on the security of nations, societies and stability. Obviously, terrorism is considered an organized and criminal event that aims to create turmoil, disrupt society's stability and order, political status and nation economy by applying 
violence and killing innocent people. Therefore, terrorism is defined "illegally applying violence with the goal of deterring public thoughts and for political targets". Others define terrorism as deterring public thought to make political goals into reality by applying organized violence, creating turmoil, threatening stability of society for dominance (Ibid, 26).

Terrorism aims at creating riot, fear and disseminating one-sided rumor to disrupt public order. Such actions would concern public and consequently provoke them to rise against political authorities for their inability in supporting the citizens. Terrorism intentionally equips itself to various media in order to fulfill his political goals in one side and to mislead security organization on the other side. Effectiveness on public thoughts and dissemination of terroristic measure through media would help terrorist group to achieve their goals. Some terrorist organizations believe that inability to disseminate their criminal actions could be an operation defeat.

Thus, efforts of terrorist organizations will manifest as they use media and advertising tools to disseminate terrorist ideas, exaggerate their role, and call the attention of public to their own perspectives. In this regard, psychologists would stop their operation if they realize actions not supported by media advertisement, because media can only disseminate reports on damages imposed to enemy. They believe mental war can be efficient and beneficial when people gets informed (Nelis, 2012: 26).

Mass media intentionally or unintentionally disseminate terrorist goals, introduce terrorist organization by covering news and reports. In fact terrorists have free of charge advertisement for their actions and media increase ads cost by propagating audience-friendly News, so they earn more income. These activities made David Broder, journalist of Washington post, to call for inaccessibility of terrorist to media. Indeed interview with terrorist groups is a sort of award for their criminal actions, because it provides an opportunity for them to explain their activities and speak to public, this in turn can encourage people to accept or confirm their criminal actions (Nelis, 2012: 32).

Numerous numbers of people who participated in terrorist actions and arrested, they professed affected by some satellite networks they decided to join terrorist organization and do suicidal or explosive operation. Displaying disastrous scenes and damages to the region can fulfill terrorist goals aiming to create fear and panic. Particularly, media compete to immediately convey terrorist events, absorb more audience including readers and viewers, therefore terrorist organizations well realized that they have to take advantage of media and information revolution for performing their criminal conspiracy, plans and operations (Ibid, 36).

\section{Fighting with terroristic approach of media}

Given that international journalism issue is an emerging event of news reports on human's lifestyle, actions, problems and difficulties, so one concern of international different media has ever been taken into consideration and it is to classify and study the matters at four international, national, personal levels and reflection the report as a media specific case. By displaying violent News of terrorist activities, the media attempt to show a unique face of Daesh in accordance with government's benefits or supporting institutions (Zhang, 2008: 26).

Copying with media terrorist approach is feasible through opposition against intemperate ideas and prevent it adverse effects on public thoughts, especially youth, therefore we can dissolve terrorist threat. So fight against terrorist phenomenon is not only possible through adopting direct security measures but it requires news framework that strengthen conversation culture and confrontation with violence perspective. Some has called for rethinking media and press activities as well as employing new concepts that intercept the spread of violence and terrorist phenomenon. By referring destructive role of some media and their influence on youth's mentality, threat for nation's security as well as reflecting a disgusting face of Islam through encouraging violence and extremist thoughts, they call for copying with published destructive information on internet and applying regulation to shut down websites who has introduced themselves with Islamic nature (Powell et al., 2011: 36).

Indeed, some satellite channels and internet websites have turned into a place for educating how to build explosive material, commit terrorist operation and to issue irrelevant judicial decree, consequently scholars and religious jurisprudence necessitate paving the way for reflecting a brilliant appearance of Islam based on justice, moderation, and good preachment.

In addition, public benefits should be supplied and discussed by making contact and holding education course between representative of official authorities and media on how to cope with media terrorist plans. In this regard, it is possible to predict and study the incidence of terrorist event and how media interact. The measure to high degree involves getting away from news space making, precautions in the area of publishing information related to terrorist events, lack of broadcasting news pertinent to terrorist crimes (Powell et al, 2011). 
Table 1. A comparison of how to arrange and cover News through media of BBC Persian, voice of America and IRNA

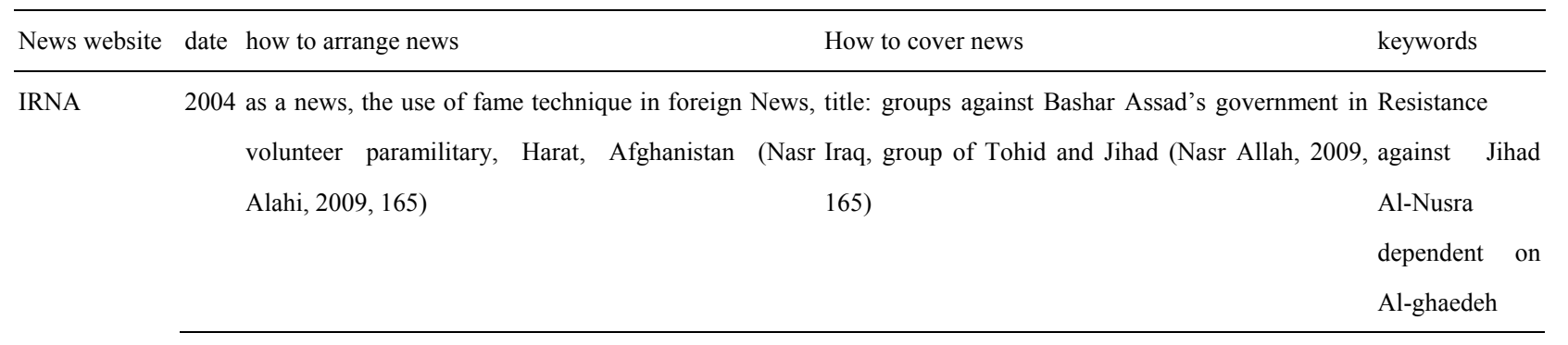

2005 nationally and internationally and based on fame: subtitle: Takfiri and suicide bomb terrorist (Nasr Jihad al-Nusra Wahhabis Taliban (Nasr Allah, 2009, 168) Allah, 2009, 168)

2006 Experienced groups (Sunni faith) who have been freed inter news: suicide bomb groups/ paramilitaries Jihad al-Nusra after Sadam Hussein's arrest joined to Al Ghaedeh

2007 difficulty in presenting reports because of presence of naming as Jihad al-Nusra group, news reflection Jihad al-Nusra groups dependent on $\mathrm{Al}$ Ghaedeh for national benefits, taken by Neinava standard towards warning against border's threat and its influence on national Shia majority in Iraq/ Al Ghaedeh terrorist group security/showing attack images, sectarian divide in Iraq

2008 (coordination of Sunni's benefits, process dependent Takfiri process dependent on Al Ghaedeh Jihad al-Nusra on Al Ghaedeh in Iraq (Hatami, 2015)

2009 based on Non Islamic fame and process dependent to mercenaries of global arrogance, Jewish American Jihad al-Nusra Al Ghaedeh, while the announcement of Iraq Muslim and Israel are oppressed

2010 highlighting by: supreme leader of revolution Terrorist, hacker groups who call themselves anti Jihad al-Nusra "Baathistt-Takfiri terrorism" Bashar-Assad government .

2011 based on strange news, daesh's literature to summarize daesh criminals- Saudi and Israel hired (Heidari, Jihad al-Nusra the name of Iraq and Sham upon announcing the stand 2014, 7) of Islamic republic of Iran as Iraq's supporter (Heidari, $2014,5)$

2012 the presence of daesh in the region and its threat for Daesh bloodthirsty group (Heidari, 2014, 6) daesh region peace (Heidari, 2014, 6)

2013 mentioning murder of civilians in Iraq and critical Salafi Islamic State/ Salafi dependent on Jaish daesh status in Iraq and Syria but no mention of al-Islam government's presence in Iraq and Syria

2014 reflection of news to Daesh situation in the region and terrorist group daesh the origins of groups like Boko Haram

2015 Blomberg American magazine, reflection of news Iraqi groups in conflict with Daesh in Ramadi are daesh based on American's awareness of exact place of going forwards the center of city and attempt to take Ramadi convoy. A reason for America's cooperation back the last area not still occupied by Daesh with Daesh 
compared to other presentation and programs of

network

2005 using softening technique of news regarding support or Islamist or Sunni militants

News coverage Sunni groups

2006 presenting soft news about Daesh activity in Iraq and insurgent Sunni Muslims (Note)

Taliban as well as showing Sunni groups in separation

in Iraq

2008 Showing Jihadist and takfiri separated from each other Jihadi militants and Sunni fighters dependent on ISIS like News different from Jihad al-Nusra and other Daesh suicide bomb attack. Downplay of fighters beside

NATO strong presence in Iraq (Hatami, 2015, 13)

2009 Emphasis on NATO control over religious and ethnic Emphasis on common aspect of Islamic republic ISIS conflicts in Iraq interest with Daesh

2010 emphasis on controlling Iraq Geopolitics status by the emphasis on NATO power against opposing groups ISIS hand of NATO forces and US in Iraq and their ability to dominate Middle East non-organized condition

2011 democracy in Iraq with NATO and America focus America existence from Iraq is a worrying. US ISIS (Baseri, 2013, 15) existence from Iraq benefits Iran.

2012 (effort to displace Daesh with Taliban- Ahmadi, Major-general, Ghasem Suleiman is a powerful man ISIS 2015, 146) who is not seen but felt. Using the word, leader instead of commander (Ahmadi, 2015, 147)

2013 effort to displace Daesh with Taliban applying militant instead of terrorist ISIS

2014 news maneuver over Taliban's dependence on Public mobilization consists of Shia resistant groups ISIS Pakistan's intelligence agency as harsh half along with against Daesh Sunni groups - destruction of Shia arranging measures against Daesh holy places In Iraq by Dash. The group kills non-Sunni and his opponents.

2015 (images of Deash's tank, ammunition were quickly Missile attack from Kezr to Daesh, Shia Turkmen's ISIS published in cyberspace as they were arriving into endeavor to fight against daesh- Daesh and regional Ramadi city. Coordinating measures towards separatism is the outcome of conflict between "attraction" and "difference" of Daesh with other democracy and Islam. Attack to Daesh's position in groups were talked so-called Jihadi Afghanistan and Syria - emphasis on common stand with Russiaplayed his role to convince other terrorist joining daesh BBC note on three illegal acts of Daesh's measures groups. Muslim against daesh- a claim that accuses and no mention of non-Islamic measure of Daesh. Iran of increasing his coalition advisors. Confronting Lack of news coverage regarding Muslim's protest with terrorist groups to describe Syrian attack to against daesh- groups called Islamic governmentDaesh's stands (Ahmadi, 2015, 146). news coverage (attack to Daesh stand by Russia (Ahmadi, 2015, 148). 




2008 news ordering as a semi-controlled and hard form Iraqi age groups (Hatami, 2015, 11)

(Hatami, 2015, 11)

\begin{tabular}{lcc}
\hline 2009 news ordering as a controlled and semi- hard form & Jihad extremist forces & \\
\hline 2010 news ordering as a controlled and semi- hard form Muslim extremists, Islamic militants occupied ------ \\
(Bashir \& Moazen, 2013, 51) & Syrian oil field (Bashir \& Moazen, 2013, 61).
\end{tabular}

2011 news ordering as a controlled and semi- hard form Daesh, Takfiri terrorist group (Bashir \& Moazen, ISIS

(Bashir \& Moazen, 2013, 52)

$2013,61)$

2012 news ordering as a controlled and semi- hard form Daesh Islamist group- Daesh Sunni group, Daesh ISIS

paramilitaries and Daesh extremist paramilitaries

2013 news ordering as a controlled and hard form Islamic government - Iraqi Shia militants leave ISIS

Syria.

2014 news ordering as a controlled and hard form, putting Another city of Iraq was also occupied by Daesh. ISIS

Daesh and Iranian forces together as a threat for Iraq's Islamic caliphate provides ground for disagreement

liberty

among Sunni Jihad groups.

2015 news ordering as a controlled and hard form, common attack to Daesh's positions in Syria-Iraqi Army ISIS

actions with Russia to attack Daesh, using 'one of wrote: during reclaiming operation of Ramadi city,

Assad's the most powerful opponents was killed"' as Iraqi military forces could go forward by area where

60 minutes fascinating News title

governmental buildings are there

Note. Insurgent

$\mathrm{BBC}$ is the oldest and largest News broadcasting establishment throughout the world. The main BBC activity is to produce program and news services. BBC's motto is: "any nation should speak with other nation in peace and tranquility". BBC belongs to center and how to control the system is determined by royal order during 10-years period. Cost for all services and BBC networks are provided from monthly expense that should be paid by families of TV owner, except world and Persian service which is paid by Britain foreign ministry. Due to support of terrorist group and changing into a media lever for Daesh, BBC Persian has again and again been protested on behalf of his audience since the formation of daesh group, and it demolishes Russian successful military operation more than any other media.

Since the beginning of terrorist group activities against resistance axis in the Middle East, BBC Persian (belongs to British queen's royal palaces) that is careful about using polite and respectful sentences has always insisted on using the word militant rather than terrorist for Daesh in order to reduce negative load of anti-human behaviors 
and interpret the story inversely. The approach of BBC suddenly changed after terrorist attack to Paris as Daesh took the responsibility of the operation, following the event BBC used the word, terrorist, for this anti-human action at all his reports. As the advancement of science, satellite, internet and mass media over the last decades, and as News networks like BBC and CNN are equipped with image transmission system and transferring global issue to far away countries as well as the ability to speak with other regions even media, they have gained the power of influence and effective presence among public thoughts (Gue, Holton \& Sun, 2012: 26). The outcome of such process is global access and public awareness of organization, leaders from international events presented by this News network (Alaberg et al, 2012: 13). Most importantly, by addressing media and displaying international events extensively and beyond journalism-communication capacity, the network focus on certain news streams through de-territorialization and nation-oriented to cover news in accordance with its policies (Hellman \& Riegert, 2012: 30).

While western nations has called Daesh a terrorist group, but BBC Persian showed no interest to call Daesh as "terrorist", because it believes other countries also avoid announcing Daesh a non-terrorist group! During one-year unsuccessful and false operation of Western coalition countries in fighting with Daesh, British Broadcasting Corporation that attempted to conceal its black history in advocating terrorist comprehensively by creating media propaganda, consequently he couldn't keep his supportive position of terrorist secrete upon facing with serious determination of Russia to fight against Daesh.

"attack to civilians", "invading forces in agreement with Bashar Assad", attack to positions of groups who call for better future of Syria, "Russia's attack is not against Daesh positions" are partial examples of BBC's destructive measures against Russian military operation in Syria over the last days. The destructive wave of BBC Persian still continues while Russia has targeted some Daesh's military bases, arsenal and headquarter such as Ahrar al-Sham, Jihad al-Nusra and etc. Russian's measures have irritated America, France, Turkey and Saudi Arabia that had officially sponsored this terrorist group in Syria over the last few years. BBC announced his disagreement with Russian attacks and stated these attacks benefit Daesh group to employ more force! The network has made a claim Russian air fighter attack to destroy terrorist groups in Syria that never answer the question why he distinguishes armed terrorist groups so that call a number of armed opponent as a moderate and others as extremist by applying a dual tag? As videos and images of crime displayed by different groups in internet indicating all are Salafi-Wahhabi and they are similar to Deash groups in way of killing opponents.

BBC has expressed his concern about Russia's attack to liberation army terrorists while he had himself criticized non-human measures of this group before it is formed! BBC call some groups as moderate armed opponent who are the same as Deash in committing non-human crimes. BBC has expressed concern about perishing terrorist groups known as Syria liberation army while "Spiegel" German magazine in report was surprised by non-human crimes of these terrorists.

According to aforementioned findings, there is a difference on the way of arrangement and how to cover News related to Iran between national website (IRNA) and international Persian-language website (BBC and Voice of America). IRNA has further emphasized on "popularity" value when broadcasting news. Two international websites, BBC and The Voice of America, have attempted to show a negative image of Iran by special focus on "contradiction and conflict". New findings suggest that high volume of published News in IRNA website is non-productive in the field of News production methods; while other websites have presented their topics in combined form (productive-driven event). Foreign relations with other countries has been the main agenda for IRNA, however BBC and Voice of America have further focused on other issues among a mass of topics related to Iran including help to terrorist groups such as Hezbollah in Lebanon and Syrian and Iraqi Shia resistance groups who support Bashar Assad's administration, calling resistance groups as Sunni minority, using the word, Islamic and Jihad group rather than Daesh group and covering non-Islamic nature of this group. "soft News" technique - meaning the main event along with background and supplementary information- is being considered by BBC, but IRNA and Voice of America have published high volume of their topics as "hard News" event. Findings of the research indicate that the greatest negative orientation against Iran has been broadcasted by Voice of America website. Portion of negative News has always been lesser for BBC compared to other media. Moreover, in terms of applying interactive facilities, two international websites have used post-electronic interactive integrated facility and link with pertinent sites and topics, but no utilization of such facilities is seen at IRNA websites.

Among integrated multi-media facility, BBC website has benefited a combination of "voice and image" while IRNA and Voice of America do not. It appears more practical research, including study of structure and how to cover News in IRNA News agency website than international News agency like "Reuters", "Agence France-Presse" and "Associated Press", could better express the difference and similarity of News networks at 
internationally. The fact can be studied in the future. To dissolve some weaknesses of the research for generalizability, a separate survey is required to assess IRIB (Islamic Republic of Iran Broadcasting) with other international TV and Radio networks such as BBC, CNN and Deutsche Welle.

\section{Conclusion and suggestion}

The current research was conducted with the goal of studying orientation and how News is covered at websites of IRNA, BBC Persian and Voice of America regarding Daesh's crisis. The present report was edited in five sections. The first section considers expressing generality on the necessity of doing research, objective, questions and overview of specialized words. The second section has explained theoretical fundamentals, research background and related studies. The third section presents the way of performing research, some explanation about data collection tool and technique. Findings taken from data analysis are also presented in the form of tables and diagrams in the fourth section. The fifth section presets a brief of research findings as well as discussion on results. It then deals with presenting limitations following a conclusion. Finally, some recommendations are presented in the form of a practical and academic form.

Over the last years, expansion of terrorist groups in the Middle East indicates a new course of security issue in the region. Quick development of Daesh terrorist group in Iraq and Syria shows that terrorist movement no longer forms in interstate and traditional form but modern globalization and communication system provide international organization and measures. Thus studying Daesh formation in the Middle East is highly significant for globalization issue. Regarding what stated in current research, Daesh is a terrorist group that has spread in the Middle East by utilizing globalization process. What is important in such field is transformation of security issue in the Middle East and transition of traditional to modern threats which has affected security studies as well. Globalization process has created objective and subjective domains of Deash in such manner that formation of fundamentalist social identity is regarded as a response against identity exuberance in globalization or global cultural assimilation. What has given popularity to Daesh today relates to his actions and utilization of this tool for advertising, military and mental operations. In a review of Daesh organizational structure, we still witness globalization element which is evident in its media foundation and council parliament. So in a study of Daesh as developing administration which is the outcome of globalization development and it uses its tools to achieve his goal, globalization can engenders new transformation that is going on and Middle East has significant importance, as a region with high potential for the occurrence of ethnic-religious conflicts, that is directing to crisis affected by the process. In other word, globalization in the Middle East is accompanied by more fundamentalism and religious gap that has added more crises to the region more than ever.

Meanwhile, function of press particularly News websites, with having multi-media and media facility in present-day society, have gained undeniable importance compared to other media. Global, regional and national condition and also complexity of political status has added more importance to the News network functioning. Due to party and ideological dependence, newspapers reflect the transformation in different intellectual perspective and they act differently to reflect and highlight the events.

Some critical perspectives have treated media news activity as a party ideological activity and consider the news an artificial product of ideology. Others also consider event reconstruction process a reflection of events in News media, and they regard News broadcast entitled "representation" meaning presenting events in a special view.

As a key element influencing on public thought, mass media generally function like a tool in the hand of authorities for foreign policy issues. Advancement of media and communicative bases is taken into account among the goals of government because of more effectiveness and control of public minds at global, regional and national level.

Therefore, engineering and news organization related to Deash differ in various News media across the world compared to political positions, in this regard, BBC Persian and voice of America was directed in a manner to show concern of Western country towards Daesh behavioral perspective. US and West are concerned about the security of their friends in the region, in one side, and probability of Daesh group return to western countries are terrible event against West and US national security in the other side. In the first phase of Daesh scenario that was successfully conducted, Daesh showed horrible and unbearable scenes in Iraq and Syria. In the second phase, The United States come into scene like Hollywood movies and introduce itself saver of people. This lie should so believable that would facilitates the next phases and steps. America had twofold behavior to show that West interest is not exposed to risk from the first day. The reason is that western countries do not accept e new threat beside their own economic problems. As a result, the process of US and west fight against Daesh should not create a new concern. On the contrary, News media, like IRNA Islamic Republic of Iran Broadcasting, attempted to show a picture of Syrian and Iraqi oppressed Muslim, for instance Daesh's violence and brutality has spread to 
West Bank and caused more oppression for defend less Palestinians.

Global arrogance first dominates people's mind through media and with the goal of brain washing. Israel and American media advertise about Daesh and assign the word "government" to it a lot, they repeat this word so much to stick in Arab people's mind that there is a Daesh coalition with powerful army. While this terrorist group includes a number of Evil men gathered from across the world with different language, blood, habits and customs. In the early 50s, America began using unconventional methods to control his opponent's thought who have been arrested, so he acts in a manner to employ them at the service of US policy. MK-LTRA plan designed by CIA (Central Intelligence Agency) is planned to change real personality of those arrested into brutal and violent people through an electronic program. Brutal and free from any human sensations massacre of Daesh groups testifies the fact. If we study the history of Daesh group, we realize that many of them have spent years in Abu Ghraib or Guantanamo prison and concentration camp where trained to the latest planned measures at Israeli service.

Coalition and plan against Daesh is gradually formed with US leadership that is indeed supports of Daesh. Of course the scenario of fight against Daesh is to advocate them, in practice, but it is planned in a way that gave them greater benefits and interests. They cannot introduce the phenomenon insignificant and partial, as the purpose of America and western countries is to operate the terrorist and brutal phenomena in long term. As a result, they introduce it a long term, extensive and time consuming process. In recent scenario, US completely take responsibility of operation and it has not assigned all affairs to Qatar, Saudi Arabia and Turkey like last years. Indeed, military officials talk about different programs. In one direction they talks about fighting against Daesh and on the other side the issue of fighting against Bashar Assad is raised. Therefore they call for Daesh perish on the condition of Bashar Assad's fall in Syria. The difference between America perspective and his partners in the region is that they want achieve the goal soon but US has set target to bring down Syrian system in slow steps.

Networks like Voice of America Persian and other related media are mainly influenced by big economic establishments and they reflect and interpret News of superior class which is far from real world. Most western media tries to meaningfully direct News. Actually the media attempt to change public thought to create the considered influence by applying judgment techniques and avoiding expressing reality contrary to their own objectives.

What we see or hear as news in current media is purposefully prioritized and they study consequence of an event based on unique perspectives. We rarely come across reports presented by correct and reliable statistics. Unpleasantly, over years of media advertisement and increasing development of information technology, judgment potential and analysis of world audience is declining within recent years. Whatever western countries did regarding nuclear discussions, it has had particular benefits using media advertisement in public diplomacy framework before and after negotiations. Generally, the media focus on public thought of Iranians inside and abroad and also a heavy space was produced for negotiators who have to react and rejects false accusations. The space still continues on behalf of the west. It should be mentioned western media make effort to discourage Iranians form their own authorities. Through false advertisement, they introduce Iran as a country that is going to construct nuclear weapons. Of course, the negative advertisement has been completely counteracted with the effort of negotiators during the last two years.

Besides, some points should be stated on BBC Persian media: impartiality is a common technique form British media to draw the attention of Iranian curious audience. The technique is abundantly observed among reports, News and BBC Persian programs. However, the principle and the effectiveness of the technique are based on organization and arrangement of the massage. For example, in a seemingly interactive program named, Nowbat e Shoma, you see that opposite and compliant opinions are raised very clearly. However, exact analysis of several cases has shown that opinion expression is formed as phone, video, email and in the same layout since designing the theme and receiving opinions. Then all opinions, difference in effectiveness of opinions expressed as telephone/email/webcam/blog are purposefully evaluated. Finally, network desirable statement is transferred to audience when designing opposite and compliant opinions in an impartiality form. Basically, the network pulls over natural guards of any audience depending on his media knowledge level and it inducts his own statement to audience with less resistance. Thus a type of indirect induction of massage happens.

\section{Suggestions}

1) The influence of satellite network on different age groups must be studied, and to what extent these networks have been viewed by adolescence. In doing so, more comprehensive analysis of using network is available for us. 
2) With regard to the modern age of communication technology, it is suggested those involved in serial and film production, especially national media, try to produce film in accordance with society's need and encourage people to watch national networks.

3) We can also provide suitable condition for producing national movies instead of watching foreign films.

4) We can also fulfill demands of Iranian audience by launching exclusive networks that dub and display up new and to date movies of world according to the needs of Iranian audience.

5) This can be done for new satellite networks which is displayed in Persian language and for Iranian audience, particularly FARSI 1 show in order to gain suitable guideline

\section{References}

Aalberg, T., Papathanassopoulos, S., Soroka, S., Curran, J., Hayashi, K., Lyengar, S. ... Rowe, D. (2013). International TV news, foreign affairs interest and knowledge: a comparative study of foreign news coverage and public opinion in 11 countries. Journalism Studies, 14(3), 387-406. http://dx.doi.org/10.1080/1461670X.2013.765636

Ahmadi, A. (2015). Iraq and Syria. Tehran, the monthly Islamic culture, year 5, No 56.

Althaus, S., \& Tewksbury, D. (2002). "Agenda Setting and the "New" News: Patterns of Issue Importance Among Readers of the Papers and Online Versions of the New York Times". Communication Research. http://dx.doi.org/10.1177/0093650202029002004

Bashir, H., \& Moazen, K. (2013). America media diplomacy regarding Islamic awakening 2011, analysis of qualitative content, Persian site, voice of America (from January 2011 to June 2011), quarterly research-scientific, Islamic Revolution Studies, year 10, No 33.

Couldry, N. (2003). Media, symbolic power and the limits of Bourdieu's field theory.

Eid, M. (Ed.). (2014). Exchanging Terrorism Oxygen for Media Airwaves: The Age of Terroredia: The Age of Terroredia. IGI Global. http://dx.doi.org/10.4018/978-1-4666-5776-2

Gilboa, E. (2009). Global Communication and Foreign Policy. I.S.U press.

Guo, L., Holton, A., \& Jeong, S. H. (2012). Transnational comparative framing: a model for an emerging framing approach. International Journal of Communication, 6, 1918-1941.

Hatami, M. R. (2015). The formation of Daesh in world media center. the monthly strategic study, (61).

Heidari, A., Ramezani, B., \& Baseri, A. (2013). Connection between using internet, satellite program and religious identity (as an abstract). Tehran, convention of identity and visual space.

Heidari, M. R. (2014). Hobab of Daesh produced by Israel, international conference of human science and behavioral studies.

Hellman, M., \& Riegert, K. (2012). Emerging transnational news spheres in global crisis reporting. In I. Volkmer (Eds.), The handbook of global media research (pp. 157-171). New Jersey: Blackwell Publishing Ltd.

http://ir.voanews.com/

http://www.bbc.com/persian

http://www.irna.ir/

Joyce, M. (2012). Digital Activism decode, The new mechanics of change. International debate education association.

Melnick, R., \& Eldor, R. (2010). Small investment and large returns: terrorism, media and the economy. European Economic Review, 54(8), 963-973. http://dx.doi.org/10.1016/j.euroecorev.2010.03.004

Nasrallah, A. (2009). Radio and television management, the quarterly, the third year, No 11.

Nellis, A. M., \& Savage, J. (2012). Does watching the news affect fear of terrorism? The importance of media $\begin{array}{llll}\text { exposure on terrorism fear. Crime \& Delinquency, } 58(5), & \text { 748-768. }\end{array}$ http://dx.doi.org/10.1177/0011128712452961

Nye, J. R., \& Joseph, S. (2008). Public Diplomacy and Soft Power. The ANNALS of the American Academy of Political and Social Science, 616(1). http://dx.doi.org/10.1177/0002716207311699

Sandboth, M. (2005). Pragmatic Media Philosophy. Retrieved from www.sandbothe.net 
Silver, R. C., Holman, E. A., Andersen, J. P., Poulin, M., McIntosh, D. N., \& Gil-Rivas, V. (2013). Mental-and physical-health effects of acute exposure to media images of the September 11, 2001, attacks and the Iraq war. Psychological science, 24(9), 1623-1634. http://dx.doi.org/10.1177/0956797612460406

Wu, H. D. (2007). A Brave New World for International News? Exploring the Determinants of the Coverage for Foreign Nations on US Websites. International Communication Gazette. http://dx.doi.org/10.1177/1748048507082841

Zhang, X. (2015). Media coverage of the ISIS threat: Transnational media and global journalism. Diss. Texas Tech University.

\section{Copyrights}

Copyright for this article is retained by the author(s), with first publication rights granted to the journal.

This is an open-access article distributed under the terms and conditions of the Creative Commons Attribution license (http://creativecommons.org/licenses/by/4.0/). 